\title{
Autosomal recessive spastic paraplegia type 20
}

INSERM

\section{Source}

INSERM. (1999). Orphanet: an online rare disease and orphan drug data base. Autosomal recessive spastic paraplegia type 20. ORPHA:101000

Autosomal recessive spastic paraplegia type 20 (SPG20) is a type of complex hereditary spastic paraplegia characterized by an onset in infancy of progressive spastic paraparesis associated with distal amyotrophy, psuedobulbar palsy, motor and cognitive delays, mild cerebellar signs (dysarthria, dysdiadochokinesia, mild intention tremor), short stature and subtle skeletal abnormalities (pes cavus, mild talipes equinovarus, kyphoscoliosis). SPG20 is due to mutations in the SPG20 gene (13q13.1), which encodes the protein spartin. 